\title{
Interest-free Microfinance in India:
}

\section{A Case Study of the Al-Khair Cooperative Credit Society}

\author{
Wasiullah Shaik Mohammed ${ }^{*}$ and Khalid Waheed ${ }^{* *}$ \\ *Research Scholar, ${ }^{* *}$ Assistant Professor \\ B S Abdur Rahman Crescent Institute of Science and Technology, India
}

\begin{abstract}
Interest-free microfinance institutions are providing efficient services around the globe including in India. The current paper is a case study research of Al-Khair - a well-known interest-free credit cooperative society in India. In this paper, the authors try to understand the modus operandi of the selected institution. The selected institution has also been evaluated in terms of various parameters such as its current status, outreach, beneficiaries, growth, and financial health. In conclusion, the authors highlight the potential challenges facing this institution and make a few recommendations for its further growth and development.
\end{abstract}

Keywords: Microfinance, Interest-free Microfinance, Islamic Microfinance, Islamic Finance, Sharīa ah, India, Multistate Cooperative Credit Society.

KAUJIE Classification: H14, H15, J33.

\section{Introduction}

Microfinance refers to the provision of financial services to low-income clients, including the selfemployed. Financial services generally include savings and credit; however, some microfinance organizations also provide insurance and payment services (Ledgerwood, 1999, p. 1).

In the last few decades, microfinance has emerged as an effective channel for providing financial services to the poor and asset-less people in India. The Raghuram Rajan Committee in its report also recog- nized 'Microfinance' as the major non-institutional channel for financial inclusion (Planning Commission, Government of India, 2009, p. 57).

During the last year (as on $31^{\text {st }}$ March 2016), Indian microfinance institutions ${ }^{(1)}$ (MFIs) have served around 39 million clients (Sa-Dhan, 2016, p. 14). This figure is just $3 \%$ of the total Indian population.

(1) A sample of 166 institutions, representing around $95 \%$ of the microfinance sector in India was used for the study by Sa-Dhan. 
Therefore, despite recent growth in client outreach and its contribution in the area of financial inclusion, the penetration of microfinance services in India has been very low. Hence, there is a scope for further expanding microfinance services by utilizing innovative alternative modes that are available.

It is a well-known fact that along with their key role in financial inclusion, there have been some bitter experiences with MFIs. The combination of minimal regulation and rapid sector growth led to an environment where customers became increasingly dissatisfied with MFIs, culminating in the microfinance (Andhra Pradesh) crisis in 2010.

Among various issues arising from conventional microfinance practices, the major one is with regards to the high rates of interest charged by MFIs (APMF Ordinance, 2010, p. 10; Malegam, 2011, p. 10). One way to tackle this issue could be to explore interestfree microfinance (IFMF).

Interest-free microfinance (also known as Islamic microfinance) prohibits receipt and payment of interest $(r i b \bar{a})$ on financial transactions. It also prohibits practices considered unfair or exploitative so as to safeguard the welfare of the people (Karim, Tarazi, \& Reille, 2008, p. 1). Interest-free Microfinance Institutions (IFMFIs) are providing efficient services in the Middle-East, North Africa, South Asia, South East Asia, Sub-Saharan Africa and Central Asia regions (Obaidullah \& Khan, 2008, pp. 25-30).

IFMF is being practiced in India for a fairly long time. IFMFIs in some nascent forms such as bayt al$m \bar{a} l$ have been used here. Some of these were established in the 1930s. For example, Patni Cooperative Credit Society was established in 1931, Muslim Fund at Tanda Bawli in 1941, and Islamic welfare societies during the 1970s (Bagsiraj, 2003, pp. 9-12).

At present a fairly large number of such institutions have been registered as Trusts, Societies, and Cooperatives and are operating in various parts of India such as Andhra Pradesh, Bihar, Delhi, Gujarat, Jammu \& Kashmir, Karnataka, Kerala, Maharashtra, Tamil Nadu, Telangana and Uttar Pradesh.

These institutions mostly provide interest-free loans (qard hasan) and collect service charges. A few of them have also started to raise and deploy funds in profit and loss sharing (mushārakah and muḍārabah), cost plus sale (murābahah) and rental based (ijärah) modes.

\section{Research Objectives and Methodology}

The present paper is based on a case study of AlKhair Cooperative Credit Society (hereafter referred to as Al-Khair).

The main objectives of the present research are:

- Understanding the modus operandi of AlKhair.

- Evaluating Al-Khair's performance in terms of outreach, operational efficiency, and financial position.

- Identifying operational and Sharī'ah issues facing Al-Khair and providing possible ways to address them.

- Evaluating the performance of Al-Khair against that of conventional MFIs.

- Documenting the operations of Al-Khair so as to bring them to the notice of researchers, most of whom may be completely unaware of even the possibility of setting up interestfree microfinance operations in the Indian context.

Al-Khair has been selected for the case study on the basis of convenience of sampling. The primary data required for the present study has been collected using a 'Questionnaire' which was shared with the Managing Director (Respondent) of Al-Khair during the visit. The opinion of the borrowers regarding AlKhair operations was collected through an informal 'interview' which was conducted with eight (8) borrowers who were selected randomly at two branches. Moreover, the authors also had informal interactions with the staff members to have a better idea of Al-Khair's operations. In addition, some of the information is also collected through telecom and Email. The secondary data related to the institution is collected from Annual Reports, websites, introductory materials, etc. Other required information has been collected from relevant books, journals, and online databases.

The collected data has been analyzed and interpreted using general statistical tools such as Percentages, Means, Graphs, Ratio Analysis and Compound Annual Growth Rates (CAGR). The conclusions drawn are based on the personal interpretations of the authors. 


\section{Review of Literature}

Interest-free microfinance is an established concept in global financial markets. The first comprehensive attempt to study the operations of IFMFIs in the Indian context is made by Bagsiraj (2003). He has done a survey of around 200 small IFMFIs operating as cooperative and welfare societies in the year 1999-2000. Due to insufficient data available from most of the institutions, the author selected only 20 institutions for final study. These institutions were evaluated in terms of their economic viability and awareness, funds accumulated, profitability, loans disbursed, etc. This research work also gives a brief idea of socio-economic performance and the various challenges confronting these institutions.

To understand the importance of al-rahn (collateral in financial transactions), a survey of five leading Muslim funds providing IFMF services in northern India was undertaken by Khan and Nisar (2004, pp. 17-34). Based on the survey, the authors opine that despite the non-recognition of al-rahn under Indian financial regulations, these funds have done impressive work by providing interest-free loans.

Ajmal (2010) in his research work has included a case study of Al-Khair. His paper broadly discusses a plan to initiate a nation-wide interest-free cooperative movement. To support this idea empirically, the author has brought the best practices of Al-Khair into the discussion. The author also cited findings of research work in which the performance of Al-Khair on aspects such as its acceptability, plural social combination (diversity in terms of gender, religion and caste), reach among Muslims and other financial parameters (on the basis of 2004-06 data) were evaluated. According to the author, the performance of Al-Khair is comparatively better than that of conventional MFIs.

An attempt to highlight the key role played by minority funds in providing micro saving facilities to Indian Muslims is made by Nisar and MizanurRahman (2012). The authors, on the basis of the case study of four Muslim funds, present the model, management strategies, governance and auditing practices of these funds. The funds were analyzed from operational efficiency, growth and Sharī'ah aspects. A special note on the need and advantages of micro savings and the difference between the operations of Muslim funds and conventional MFIs is enlightening. In conclusion, the authors stress that minority funds should expand their scope, refine their audit mechanisms and make their results available to the public.

A case study of Athani - an IFMFI located in Kerala - is reported by Ameer (2013, pp. 103-116). In this paper, the author studies the impacts of IFMF services on poverty alleviation. The author highlights the key issues pertaining to these institutions such as fund mobilization, training and development, repayment problems, etc.

As most of the Indian IFMFIs are lending funds against service charges, a conceptual framework on service charges, its calculation and method of collection from Sharī ah and costing perspectives has been dealt with by Khatkhatay and Nisar (2014, pp. 33-49). In their work, the authors discuss the Sharī'ah stipulations related to the collection of service charges on interest-free loans. They also evaluate the rationale of the applicability of service charges from costing, accounting, and financing perspectives. In conclusion, the authors propose a scientific costing system and the Re-days method (which is based on the period of utilization and amount of the loan) of calculation for service charges as the possible solution.

The literature survey indicates that there have been a few notable efforts in the development of literature in the area of IFMF in the Indian context. But in comparison to the related time period (nearly a century since the existence of this concept) and the literature developed in the area of conventional microfinance, these efforts seem negligible.

Moreover, except in a few research works, the modus operandi, regulatory framework, operational and Shari ${ }^{-}$ah issues, and the socio-economic impacts of IFMFIs have not been dealt with in detail. Hence, the present study aims to reduce the research gap by presenting detailed information relating to Al-Khair's operations. 


\section{Introduction to Al-Khair Cooperative Credit Society}

\subsection{Introduction}

Al-Khair is a Multistate Credit Cooperative Society (MSCCS) located at Patna, Bihar. It is registered under the Multistate Cooperative Societies Act (MSCSA), 2002. The main objective of the Society is to alleviate poverty through cooperation and interestfree credit.

As per the available information, as on March $31^{\text {st }}, 2016$, it had 13 branches spread across Bihar, Delhi, Jharkand and Uttar Pradesh. The Society had raised a total share capital of INR 13.3 million $^{(2)}$. It had mobilized deposits of INR 69.7 million and its total loans outstanding are INR 73.9 million. It has around 14,000 members and around 3,000 loan beneficiaries (Al-Khair, 2016, pp. 5-13). For more details please refer to Table 1 below.

The basic guiding principle for Al-Khair is 'Benefit for all but exploitation of none'. Following this principle, the institution has helped people get rid of ruthless moneylenders who charge exorbitant interest. Since its inception, the institution does not receive or pay interest on loans and deposits.

\subsection{Applicable Regulations}

As mentioned above, Al-Khair is registered under the Multistate Cooperative Societies Act (MSCSA), 2002. This act is applicable throughout India and regulates cooperative societies whose operations are not confined to a single state.

As discussed by Mohammed, Shaik, Abdur Raqeeb, and Waheed, (2016, p. 271) in their earlier research, a Society is permitted to draft its own byelaws in consistence with the provisions of the Act, as per Chapter-II, Section 10 (1\&2) of MSCSA 2002. The bye-laws should include details related to the name, address, area of operation, sources of funds, application of funds, disbursement of net-profits, etc. The bye-laws drafted by an MSCS need to be approved by the Central Registrar. Once approved, the bye-laws stand as the legal document upon which the operations of the Society are reviewed.
Unlike the other financial regulations under which fund mobilization and deployment face major hurdles, the MSCA 2002 provides (technical) flexibility to IFMFIs to raise and deploy funds on interestfree modes.

Considering this fact, the management registered Al-Khair under this Act. Since its registration, the Society has been submitting annual reports, returns and other required documents to the Central Registrar and to the Government of India (GOI). As of now, the Society is successfully serving the population and contributing to India's goal of 'Hundred Percent Financial Inclusion'.

\subsection{Operational Structure and Governance}

In a cooperative, the members are the key component of the operational structure and the final authority to select the management and lay down the operational guidelines. Therefore, in the case of Al-Khair too, members have the same vital role. Membership within its approved area of operation is open to all. For membership, one has to subscribe at least 10 shares of INR 10/- each and pay a one-time admission fee and a donation.

The Annual General Meeting (AGM) of Al-Khair is held every year and all the key decisions are taken by the members. Members elect the Board of Directors. As on $31^{\text {st }}$ March 2016, the Board of Directors consisted of 16 members out of which one member is elected as Chairman, one as Vice Chairman and one as Managing Director. The Managing Director looks after the daily operations of the Society. The Society has also constituted a Standing Committee and a Central Loan Committee to increase operational efficiency. An independent chartered accountant is appointed as the auditor of the Society.

Every year the Board of Directors presents the performance report of the Society to the members. Based on the annual report, the future course of action and budget are decided. 
Table (1) Profile of Al-Khair during the period 2011 to 2016

\begin{tabular}{|c|c|c|c|c|c|c|}
\hline Particulars & Units & 2011-12 & 2012-13 & 2013-14 & 2014-15 & 2015-16 \\
\hline Share Capital & $\begin{array}{c}\text { INR } \\
\text { Million } \\
\end{array}$ & 2.9 & 4.3 & 6.3 & 9.2 & 13.3 \\
\hline Reserves \& Surplus & $\begin{array}{c}\text { INR } \\
\text { Million } \\
\end{array}$ & $(0.22)$ & $(0.18)$ & $(0.29)$ & $(0.31)$ & 0.05 \\
\hline Total Deposits Outstanding & $\begin{array}{c}\text { INR } \\
\text { Million } \\
\end{array}$ & 21.1 & 30.6 & 40.8 & 55.5 & 69.7 \\
\hline Total Loan Outstanding & $\begin{array}{c}\text { INR } \\
\text { Million } \\
\end{array}$ & 20.6 & 29.7 & 40.0 & 55.2 & 73.9 \\
\hline Total Fixed Assets & $\begin{array}{c}\text { INR } \\
\text { Million } \\
\end{array}$ & 0.26 & 0.32 & 0.61 & 0.61 & 0.52 \\
\hline Cash and Bank Balance & $\begin{array}{c}\text { INR } \\
\text { Million }\end{array}$ & 3.6 & 5.8 & 7.0 & 9.3 & 9.4 \\
\hline Total Assets & $\begin{array}{c}\text { INR } \\
\text { Million }\end{array}$ & 24.4 & 36.0 & 48.0 & 65.2 & 83.9 \\
\hline Total Income & $\begin{array}{c}\text { INR } \\
\text { Million } \\
\end{array}$ & 3.5 & 5.0 & 6.7 & 9.5 & 13.2 \\
\hline Total Expenditure & $\begin{array}{c}\text { INR } \\
\text { Million }\end{array}$ & 3.5 & 4.9 & 6.8 & 9.5 & 13.0 \\
\hline Net Surplus/Deficit & $\begin{array}{c}\text { INR } \\
\text { Million } \\
\end{array}$ & 0.01 & 0.1 & $(0.1)$ & $(0.02)$ & 0.2 \\
\hline Deposits collected (Cumulative) & $\begin{array}{c}\text { INR } \\
\text { Million }\end{array}$ & 71.77 & 107.3 & 178.4 & 240.33 & 311.6 \\
\hline Loans Disbursed (Cumulative) & $\begin{array}{c}\text { INR } \\
\text { Million }\end{array}$ & 16.35 & 26.6 & 36.7 & 68.31 & 93.7 \\
\hline $\begin{array}{l}\text { Total No. of Members } \\
\text { (Cumulative) }\end{array}$ & Nos & 5,221 & 6,489 & 8,387 & 10,993 & 14,067 \\
\hline $\begin{array}{l}\text { Total No. of Deposit Accounts } \\
\text { (Cumulative) }\end{array}$ & Nos & 13,807 & 16,622 & 20,292 & 24,263 & 28,201 \\
\hline $\begin{array}{l}\text { Total No. of Loan Beneficiaries } \\
\text { (Cumulative) }\end{array}$ & Nos & 1,200 & 1,520 & 1,855 & 2,321 & 2,998 \\
\hline $\begin{array}{l}\text { Total No. of Branches } \\
\text { (Cumulative) }\end{array}$ & Nos & 8 & 8 & 10 & 11 & 13 \\
\hline
\end{tabular}

(Data Source: Al-Khair Annual Reports for the period 2011 to 2016, Published by Al-Khair Cooperative Credit Society, Patna, India.)

The primary services of the Society include deposit (saving) and loan facilities. These services are discussed in detail in the following paragraphs.

\subsection{Data Collected using Questionnaire}

The questionnaire utilized to collect primary data is adopted and modified from the previous research (Bagsiraj, 2003, pp. 183-202). The questionnaire consists of 35 questions in total covering key aspects such as the institution's profile, outreach, financial position, operational policy, operational efficiency and issues facing the institution.
As per the information provided, as on March $31^{\text {st }}$ 2016, the total number of employees working at AlKhair is 92 . The total number of members is around 14,067 . Out of the total members, 3,231 are women; they constitute about $23 \%$ of the total members. The total number of loan beneficiaries is 3,000 ; they account for around $21 \%$ of the total members. The loan amount ranges between INR 1,000 and INR 100,000 with tenures of 3 months to 12 months.

Al-Khair has implemented a centralized Enterprise Resource Planning (ERP) system integrating 
Collection Machine, Tally, Online Payments and MS Office. It has not yet initiated quality control systems such as the International Organization for Standardization (ISO) audit but undertakes regular internal reviews and checks.

To create awareness among employees about the operations and to discuss various work-related issues, Al-Khair organizes employee training programs every month. Occasionally it also organizes training programs for its members, depositors, and customers. However, no program to educate members other than Muslims about interest-free finance has been organized.

On the aspect of Shari'ah compliance, though Sharī'ah scholars are being consulted as required, a regular Sharī'ah audit of Al-Khair operations has not been conducted and there is no independent Shari ${ }^{-}$ah Board appointed. However, at the time of data collection, the authors were informed that the initial study of Al-Khair's operations from a Sharī'ah perspective was in process and the proposal for a regular Sharī ah audit is under consideration.

\section{The Respondent listed the following problems:}

- No middle-class support - meaning people from middle and upper-middle-income strata do not associate with the institution.

- Insufficient training and development programs.

- Bad debt issues.

- No return to depositors.

- Know-Your-Customers (KYC) issues.

- High cost of technology.

- Lack of skilled personnel.

- Lack of legal support meaning no favorable regulatory environment.

- No microinsurance product.

- Lack of public awareness.

During data collection, the authors also interacted with eight (8) borrowers who were selected at random at Patna Central and Phulwari Sharif branches. The interaction was based on an informal interview with unstructured questions on various aspects of Al-Khair's services.
It was found that the borrowers were unable to differentiate between the key features of various products offered by the Society. Moreover, except in a few cases, most of the borrowers were not aware of the concepts of interest, service charges, and profit and loss sharing, etc. In response to the question relating to the impact of Al-Khair's services on their lives, the customers confirmed (informally) that there is a positive impact on the economic and social aspects of their lives.

The authors of this paper later provide broad recommendations that may help Al-Khair in addressing some of the listed issues.

\subsection{Details of Deposit Products}

The major portion of funds are mobilized in the form of deposits. As stated above, as of March $31^{\text {st }}, 2016$, the Society has mobilized deposits of INR 69.7 million through around 24,500 deposit accounts (AlKhair, 2016, pp. 9 \& 13). There are six deposit products $^{(3)}$ available for the depositors as presented in Table 2 below.

The readers may note that until 2014-15, it was not compulsory for customers to become members to open a deposit account. Moreover, there is also no restriction on members opening multiple deposit accounts. Due to these factors, the total number of deposit accounts is more (which is 24,500) than the total number of members (which is 14,000).

\subsection{Details of Loan Products}

Al-Khair provides demand and business loans to its members. Members are eligible to take loans only after three months of their membership. As on March $31^{\text {st }}, 2016$, the Society has loans outstanding of INR 73.9 million which were disbursed to more than 3,000 members (Al-Khair, 2016, p. 13). There are 5 types of loan products available for borrowers as presented in Table 3 below.

It is noteworthy to mention here that in case of all the business loans, Al-Khair usually shares $30 \%$ of the profit. In case of murābahah loans, it collects $8 \%$ to $10 \%$ on the cost of the assets/goods as its profit margin.

(3) The information relating to deposit and loan products are based on the introductory brochure collected during the visit. 
Table (2) Details of Al-Khair Deposit Products

\begin{tabular}{|c|l|c|l|c|}
\hline S. No. & \multicolumn{1}{|c|}{ Product Name } & Min. Amount & Lock-in Period & $\begin{array}{c}\text { No. of Accounts } \\
\text { as on 31-03-2016 }\end{array}$ \\
\hline 1 & Daily Deposit Account & INR 10 & One Month & 17,025 \\
\hline 2 & Amanat Account & INR 10 & Nil & 7,127 \\
\hline 3 & Sahyog Account & INR 10 & Six Months & 46 \\
\hline 4 & Haj Account & INR 10 & At the time of Haj & 89 \\
\hline 5 & Child Account & INR 10 & Nil & 160 \\
\hline 6 & Earmarked Fund & INR 10 & Until the repayment of the earmarked loan & 8 \\
\hline
\end{tabular}

(Data Source: Introductory Material Published by Al-Khair Cooperative Credit Society, Patna, India.)

Table (3) Details of Al-Khair Loan Products

\begin{tabular}{|c|l|l|l|l|}
\hline S. No. & Product Name & Loan Amount & $\begin{array}{l}\text { Loan } \\
\text { Period }\end{array}$ & Security Demanded \\
\hline 1 & Demand Loan & INR 1,000 to 25,000 & 12 Months & $\begin{array}{l}\text { Gold, Bank cheques, Member Guarantee } \\
\text { (only for loans above INR 5,000) }\end{array}$ \\
\hline 2 & $\begin{array}{l}\text { Short-Term Business } \\
\text { Loan (STBL) }\end{array}$ & INR 5,000 to 50,000 & 3 Months & Same as above \\
\hline 3 & $\begin{array}{l}\text { Mid-Term Business } \\
\text { Loan (MTBL) }\end{array}$ & INR 5,000 to 50,000 & 8 Months & Same as above \\
\hline 4 & Business Loan & INR 50,000 to 100,000 & 12 Months & Same as above \\
\hline 5 & Murābahah Loan & Cost Plus Margin & 12 Months & $\begin{array}{l}\text { 25\% of the Murăbahah Sale Price as } \\
\text { Down Payment }\end{array}$ \\
\hline
\end{tabular}

(Data Source: Introductory Material Published by Al-Khair Cooperative Credit Society, Patna, India.)

\subsection{Nature and Mechanism of Loan Products}

\subsubsection{Demand Loan:}

Demand loans are similar to qard hasan loans. In demand loans, the borrower applies for a loan providing all the required details in the Loan Application Form (including KYC). Al-Khair personnel verify the details and asses the repayment ability of the borrower. After all the due diligence and deposit of security, the loan is issued to the borrower. Security such as gold, post-dated cheques, property papers, guarantees from members, is demanded from the borrowers. The applicable service charges are levied and debited from the loan amount at the time of sanction of the loan and recovered as part of the installments (inclusive). The borrower visits Al-Khair office and makes the loan installment payments. In some cases, the collector/ business facilitator visits the borrower to collect the installments. On payment of the last installment, the loan is closed and loan security is released.

\subsubsection{Business Loans:}

Business loans are supposed to be structured as mushārakah (joint venture) and mud̄arabah (equity). In practice, the borrower applies for a business loan. Al-Khair personnel asses the business of the borrower and confirm the viability of the business. The borrower gives a figure of profit he/she expects to make in the business. Al-Khair and the borrower negotiate the profit sharing ratio. On the basis of the agreed sharing ratio (usually 30:70), Al-Khair's share of profit in terms of amount is determined by multiplying the sharing ratio with the expected profit figure given by the borrower. Al-Khair's share of profit (amount) is debited to the loan at the time of sanction of loan and recovered as part of the installments. The borrower visits Al-Khair office and makes the loan installment payments. In some cases, the collector/business facilitator visits the borrower to collect the installments. On payment of the last installment, the loan is closed and security is released. 


\subsubsection{Murābahah Loan:}

In case of muräbahah loans, the customer identifies the required goods (durable/consumable) and submits the quotation to Al-Khair. Al-Khair finances the goods adding its profit margin. The customer pays $25 \%$ of the muräbahah sale price as a down payment to Al-Khair. The actual cost of goods is paid directly to the vendor on spot by Al-Khair. The customer pays Al-Khair the balance amount in installments. In some cases, the goods are purchased wholesale by Al-Khair and sold to customers on installments.

\subsection{Sources of Income}

As per the available information, the following are the main sources of income:

- a one-time admission fee of INR 25 and donation of INR 25 collected at the time of membership registration.

- an account maintenance fee of INR 30 per annum collected from depositors.

- the services charges collected on demand loans.

- the charges collected as a share of profit on business loans.

- the profit from murābahah sales.

As on March $31^{\text {st }}, 2016$, Al-Khair had generated a total income of INR 13.2 million (Al-Khair, 2016, p. 14). Apart from the regular income, the Society is also collecting charitable donations to carry out its social welfare activities.

\section{Performance Analysis of Al-Khair Operations}

The performance of Al-Khair can be analyzed in terms of the following two broad sets of performance measurement indicators adopted and modified from similar research (Ashraf, Hassan, \& Hippler III, 2014, p.163):

a) Outreach Measures: The outreach measures are the number of members, depositors, deposit accounts, beneficiaries, loan accounts, deposits collected, loans disbursed, branches, average size of deposits and average size of loan, etc. The performance of Al-Khair on the selected indicators is measured using the Compound Annual Growth Rate (CAGR). b) Overall Financial Performance Measures: The financial performance of Al-Khair is measured in terms of growth of selected para-meters such as share capital, reserves, net worth, deposits, loans out-standing, fixed assets, cash and bank balance, assets, income, expenditure and net surplus/deficit. The performance is also measured using ratios such as share capital, deposits, and loans to total liabilities and to net worth, fixed assets and cash/bank balance to total assets, cost/expenditure to total loans outstanding, etc.

\subsection{Outreach Measures}

As per information presented in Table 1 above, the total number of members (cumulative figure) at the end of the year 2011-12 was 5,221 which increased to 14,067 in 2015-16 (Al-Khair, 2016, p. 9). This means that in the last five years, membership has grown with a CAGR of $28 \%$ p.a.

The number of deposit accounts at the end of year 2011-12 were 13,807 (Al-Khair, 2013, 9) which increased $^{(4)}$ to 28,201 in 2015-16 (Al-Khair, 2016, p. 9). This means that the deposit accounts have grown with a CAGR of $19.5 \%$ p.a.

The total deposits collected at the end of 2011-12 were INR 71.7 million $^{(5)}$ (Al-Khair, 2012, p. 8), which increased to INR 311.6 million in 2015-16 (Al-Khair, 2016, p. 8). This means that the deposits of the Society have increased at an impressive CAGR of $44.4 \%$ p.a.

The average amount per deposit account in 201213 was INR 2,140 which increased to INR 2,529 in 2015-16. This means that the size of deposit per account has marginally grown with a CAGR of $5.7 \%$ p.a.

The number of beneficiaries at the end of the 2011-12 was 1,200, which increased to 2,998 in

(4) As per Al-Khair, 2015, p. 9, the opening balance of deposit $\mathrm{A} / \mathrm{c}$ for $2014-15$ is 20,656 and the accounts (net) increase during the year is 3,607 . Hence, the closing balance for 201415 is 24,263 . When the accounts (net) increase of 3,938 (4,560 - 622) during 2015-16 (mentioned on p. 9 of Al-Khair, 2016) is added to the 24,263 (closing balance of 2014-15) then the closing balance for $2015-16$ becomes 28,201 . This figure is miscalculated in Al-Khair, 2016.

(5) Net of total deposits and opening balance. INR. 85,863,396$14,090,021=71,773,375$. 
2015-16 (Al-Khair, 2016, p. 9). This means that the loan beneficiaries have grown with a CAGR of $25.7 \%$ p.a.

The total value of loans disbursed at the end of 2011-12 were INR 16.3 million, which increased to INR 93.7 million in 2015-16 (Al-Khair, 2016, p. 8). This means that the loan disbursement has grown at an impressive CAGR of $54.7 \%$ p.a.
The average amount disbursed per loan account in 2012-13 was INR 6,727 which increased to INR 8,477 in 2015-16. This means the average size of loan has grown marginally with a CAGR of $8 \%$ p.a.

In the year 2011-12 the Society had 8 branches and in 2015-16 it increased to 13 . This means that the number of branches has increased very slowly on an average of one branch per year. For more details please refer to Graph 1 below.

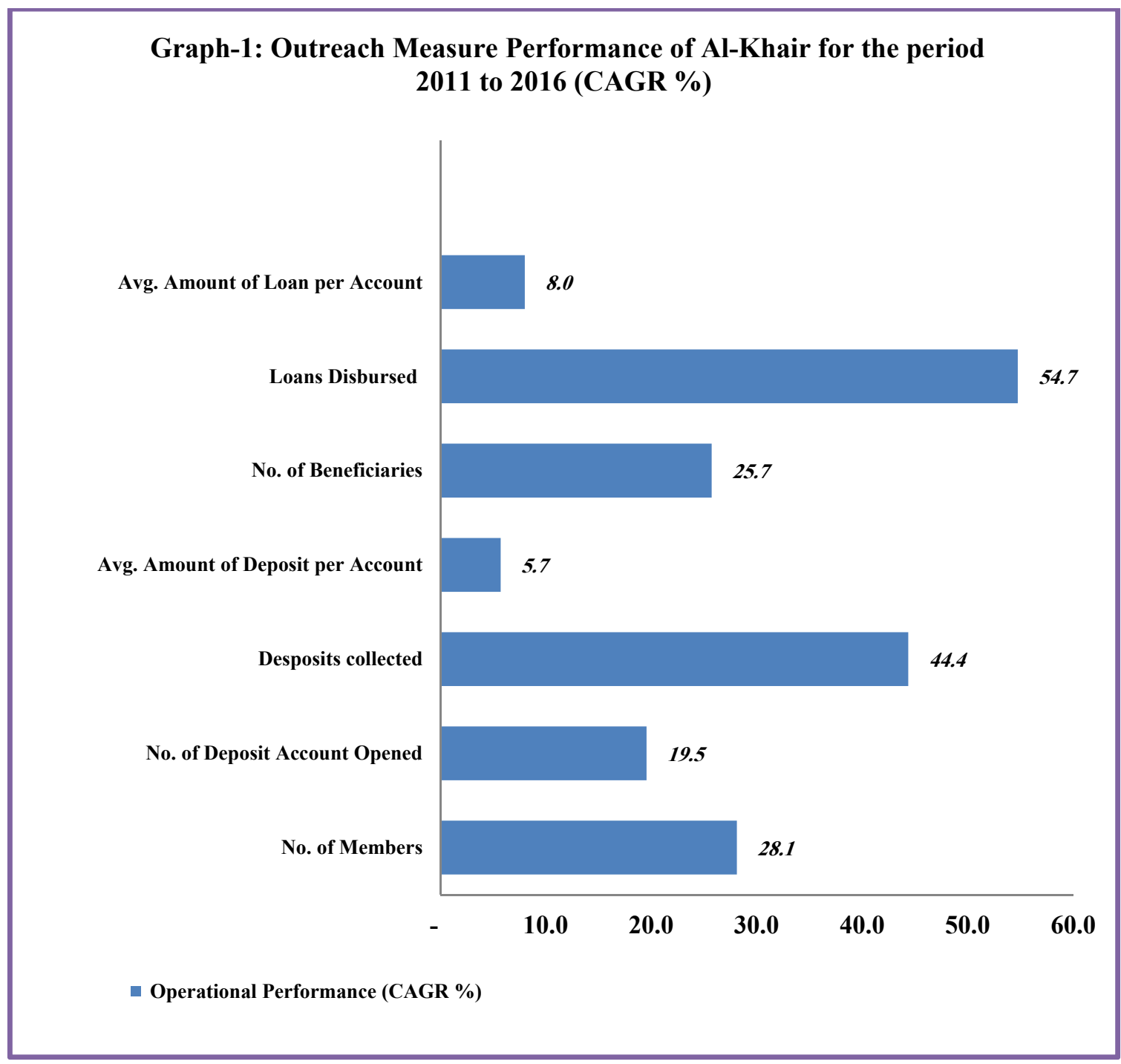

(Data Source: Al-Khair Annual Report for the period 2011 to 2016, Published by Al-Khair Cooperative Credit Society, Patna, India.) 


\subsection{Overall Financial Performance Measures}

In terms of financial performance, it can be seen from Table 1 above, the share capital of Al-Khair at the end of 2011-12, 2012-13, 2013-14, 2014-15 and 2015-16 respectively was INR 2.9 million, INR 4.3 million, INR 6.3 million, INR 9.2 million and INR 13.3 million.

The share capital during the period 2011 to 2016 has increased with an impressive CAGR of $46.5 \%$ p.a. This indicates the continuing association of new members with the Society throughout the period.

The reserves of Al-Khair at the end of 2011-12, 2012-13, 2013-14, 2014-15 and 2015-16 were INR 0.22 million, INR -0.18 million, INR -0.29 million, INR -0.31 million and INR 0.05 million respectively.

The Society has been making marginal losses during the earlier four years of the five-year period of the study. The reserves became positive in 2015-16, which means the Society was able to wipe out the accumulated losses. Contrary to first impressions conveyed by the above figures, the Society has in fact been operating throughout the period of study at about breakeven as a result of deliberate policy of not charging its borrowers more than its cost of operations. The profit earned in the latest year has arisen out of its business loans, which were introduced recently with the intention of paying a profit/dividend.

The outstanding deposits of Al-Khair at the end of 2011-12, 2012-13, 2013-14, 2014-15 and 2015-16 were INR 21.1 million, INR 30.6 million, INR 40.8 million, INR 55.5 million and INR 69.7 million respectively. The deposits have increased with a commendable CAGR of $34.9 \%$ p.a. This indicates a consistent increase in the Society's ability to mobilize funds.

The loans outstanding of Al-Khair at the end of 2011-12, 2012-13, 2013-14, 2014-15 and 2015-16 were INR 20.6 million, INR 29.7 million, INR 40.0 million, INR 55.2 million and INR 73.9 million respectively. The loans outstanding have increased with an impressive CAGR of $37.7 \%$ p.a. This indicates a consistent increase in the Society's ability to disburse funds or provide loans to its members.
The fixed assets of Al-Khair at the end of 201112, 2012-13, 2013-14, 2014-15 and 2015-16 were INR 0.26 million, INR 0.32 million, INR 0.61 million, INR 0.61 million and INR 0.52 million respectively. The fixed assets of Al-Khair have increased with a CAGR of $18.9 \%$ p.a. This indicates that the Society is very much cautious in utilizing the funds to create fixed assets.

The cash and bank balances of Al-Khair at the end of 2011-12, 2012-13, 2013-14, 2014-15 and 2015-16 were INR 3.6 million, INR 5.8 million, INR 7 million, INR 9.3 million and INR 9.4 million respectively. The cash and bank balances of Al-Khair have increased with a CAGR of $27.0 \%$ p.a.

The CAGR of cash (27.0\%) which is less than the CAGR of share capital (46.5\%) and total assets (36.1\%) indicates that the Society has improved cash management, particularly in the latest year.

Total assets of Al-Khair at the end of 2011-12, 2012-13, 2013-14, 2014-15 and 2015-16 were INR 24.4 million, INR 36 million, INR 48 million, INR 55.3 million and INR 83.9 million respectively. In the last five years, total assets of Al-Khair have grown with an impressive CAGR of $36.1 \%$ p.a. This indicates that the Society's operations have grown at a notable pace.

The total income of Al-Khair in 2011-12, 201213, 2013-14, 2014-15 and 2015-16 was INR 3.5 million, INR 5 million, INR 6.7 million, INR 9.5 million and INR 13.2 million respectively. It has increased with a commendable CAGR of $39.7 \%$ p.a.

Assessing the Society's income growth in relation to the growth in its assets one can see that the Society has been able to maintain not only its growth momentum but also ensured that its revenue has kept pace with the growth of its assets.

The total expenditure of Al-Khair in 2011-12, 2012-13, 2013-14, 2014-15 and 2015-16 was INR 3.5 million, INR 4.9 million, INR 6.8 million, INR 9.5 million and INR 13 million respectively. It has increased with a CARG of $39.3 \%$ p.a. This indicates that the Society's cost of operations is under control as it has been increasing proportionately to the increase in operations. For more details refer to Table 4 below: 
Table (4) YoY Performance of Al-Khair during the period 2011 to 2016

\begin{tabular}{|l|c|c|c|c|c|}
\hline \multirow{2}{*}{\multicolumn{1}{|c|}{ Particulars }} & \multicolumn{3}{c|}{ YOY Growth Rate \% } & \multirow{2}{*}{ CAGR \% 2011-16 } \\
\cline { 2 - 5 } & $\mathbf{2 0 1 2 - 1 3}$ & $\mathbf{2 0 1 3 - 1 4}$ & $\mathbf{2 0 1 4 - 1 5}$ & $\mathbf{2 0 1 5 - 1 6}$ & \\
\hline Share Capital & 50.7 & 45.6 & 45.7 & 44.1 & 46.5 \\
\hline Total Deposits Outstanding & 45.3 & 33.4 & 35.9 & 25.7 & 34.9 \\
\hline Total Loan Outstanding & 44.4 & 34.7 & 38.0 & 34.0 & 37.7 \\
\hline Total Fixed Assets & 23.1 & 90.6 & - & $(14.8)$ & 18.9 \\
\hline Cash and Bank Balance & 59.9 & 20.2 & 34.2 & 0.9 & 27.0 \\
\hline Total Assets & 47.4 & 33.2 & 36.0 & 28.5 & 36.1 \\
\hline Total Income & 43.3 & 35.1 & 41.7 & 38.9 & 39.7 \\
\hline Total Expenditure & 40.2 & 40.8 & 39.7 & 36.5 & 39.3 \\
\hline
\end{tabular}

(Data Source: Al-Khair Annual Report for the period 2011 to 2016, Published by Al-Khair Cooperative Credit Society, Patna, India.)

In terms of ratio analysis, it can be seen from Table 5 below, the share capital to total liabilities of Al-Khair for the year $2015-16$ is $15.8 \%$, whereas the mean for the same for last five years (2011-16) is $13.4 \%$. This shows that though the leverage of the Society is relatively high, it is within the normal range for a banking type of institution. The bye-laws for cooperative societies usually stipulate a maximum share capital to deposit ratio of 1:10 (10\%). It can be seen that Al-Khair's ratios are within this ceiling.

The deposits to total liabilities ratio for the year $2015-16$ is $83.1 \%$, whereas the mean for the same ratio for last five years $(2011-16)$ is $84.9 \%$. This indicates that deposits have been the major source of funds for Al-Khair.
The net worth of Al-Khair for the year 2015-16 is INR 13.3 million, whereas the average net worth for last five years (2011-16) is INR 7 million.

The deposit to net worth ratio for the year 201516 is $523 \%$, whereas the mean for the same ratio for last five years (2011-16) is 669\%. This indicates that deposits are 5 times of the net worth of Al-Khair. As per the applicable regulations, the Society can mobilize deposits up to 10 times of its net worth. However, the figure above indicates that Al-Khair is mobilizing around $50 \%$ of the stipulated ceiling. Hence, it is not fully utilizing its mobilizing capacity and therefore its full growth potential.

Table (5) Ratio Analysis of Al-Khair for the period 2011 to 2016

\begin{tabular}{|l|c|c|c|c|c|c|}
\hline \multirow{2}{*}{\multicolumn{1}{|c|}{ Particulars }} & \multicolumn{7}{c|}{ Ratios in \% } \\
\cline { 2 - 7 } & $\mathbf{2 0 1 1 - 1 2}$ & $\mathbf{2 0 1 2 - 1 3}$ & $\mathbf{2 0 1 3 - 1 4}$ & $\mathbf{2 0 1 4 - 1 5}$ & $\mathbf{2 0 1 5 - 1 6}$ & Mean \\
\hline Share Capital to Total Liabilities & 11.8 & 12.0 & 13.2 & 14.1 & 15.8 & 13.4 \\
\hline Deposits to Total Liabilities & 86.2 & 85.0 & 85.1 & 85.0 & 83.1 & 84.9 \\
\hline Net-worth (INR Million) & 2.7 & 4.2 & 6.0 & 8.9 & 13.3 & 7.0 \\
\hline Deposits to Net-worth & 790 & 735 & 676 & 623 & 523 & 669 \\
\hline Loans to Deposits & 97.6 & 97.0 & 97.9 & 99.5 & 106.0 & 99.6 \\
\hline Total Loans to Total Assets & 84.1 & 82.4 & 83.3 & 84.5 & 88.1 & 84.5 \\
\hline Fixed Asset to Total Assets & 1.1 & 0.9 & 1.3 & 0.9 & 0.6 & 1.0 \\
\hline Cash and Bank Balance to Total Assets & 14.8 & 16.1 & 14.5 & 14.3 & 11.2 & 14.2 \\
\hline Total Income to Total Funds & 14.6 & 14.3 & 14.3 & 14.8 & 15.9 & 14.8 \\
\hline Total Expenditure to Total Loans O/S & 16.8 & 16.3 & 17.1 & 17.3 & 17.6 & 17.0 \\
\hline
\end{tabular}

(Data Source: Al-Khair Annual Reports for the period 2011 to 2016, Published by Al-Khair Cooperative Credit Society, Patna, India.) 
As far as the utilization of deposits for loan disbursement is concerned, Al-Khair stands at $106 \%$ in 2015 16 , whereas the mean for the same ratio for the last five years remained $99.6 \%$. This reflects a high utilization of deposits to create loans.

Out of the total assets available, Al-Khair has utilized $88.1 \%$ of assets for creating loans during the year 2015-16. Whereas the mean for loans to total assets ratio for the period of last five years is $84.5 \%$. This also indicates that the Society is making optimum utilization of its funds.

Out of the total assets available, Al-Khair has utilized $0.6 \%$ of assets for creating fixed assets during the year 2015-16. Whereas the mean for the fixed assets to total assets ratio for the period of last five years is $1 \%$. This reflects the cautious approach of the Society in creating fixed assets.

The liquidity ratio (cash and bank balance to total assets) for the year $2015-16$ is $11.2 \%$ of the total assets whereas the mean for the same ratio for last five years is $14.2 \%$. In view of the Society's objective of avoiding interest-based transactions, its access to funds to meet emergency liquidity needs is likely to be greatly constrained.

In addition, more than $97 \%$ of its deposits are demand deposits (Al-Khair, 2016, p. 17). In this perspective, the liquidity ratio being maintained by the Society appears to be dangerously low.

The total income to the total fund ratio for the year $2015-16$ is $15.9 \%$, whereas the mean for the same for last five years is $14.8 \%$. This means that the Society is generating around $15 \%$ gross return on deployment of total funds. Though this ratio is acceptable, however, there is still scope for increasing its income by deploying funds in profit-based business loans.

The total expenditure to the total loans outstanding for the year $2015-16$ is $17.6 \%$, whereas the mean for the same ratio for last five years is $17 \%$. This means that the Society is incurring around $17 \%$ cost on a rupee loan it is disbursing. This ratio seems to be very high and needs to be decreased by increasing the fund base and by controlling the costs.

On the basis of the above analysis, it can be concluded that Al-Khair is one of the operationally efficient institutions in the area of IFMF. The overall performance of Al-Khair during the last five years (2011-16) is good. However, it needs to work on cost control and increasing its funds base. It is because the customers of IFMFIs expect them to provide loans not only on interest-free basis but also at comparatively lower cost than conventional financial institutions.

This is all the more necessary as the Society has very little scope for generating efficiencies in the area of fund management, having already overextended itself in deploying funds in loans at the cost of maintaining an optimum level of liquidity. It is worth noting that Al-Khair is working on a not-for-profit basis. A major source of its income comes from the service charges it collects on loans. But to become self-sufficient, it needs to work on generating income from either non-fund based alternate sources or increasing the proportion of business loans.

\section{Comparative Performance Analysis of Al-Khair with Indian Microfinance Industry}

In order to understand how the Indian microfinance sector is moving and contributing to the broader objective of 'financial inclusion', one needs to refer to real-time empirical data regarding the industry.

To fulfill this requirement, Sa-Dhan, as the leading association of Indian community development finance institutions, has been successfully publishing 'The Bharat Microfinance Report' for the past thirteen years. The report produced by Sa-Dhan on an annual basis provides readers in-depth information on the performance of the Microfinance sector, evaluating selected Indian MFIs on various parameters. Similar to its earlier reports, this year too, Sa-Dhan has come up with the 'The Bharat Microfinance Report 2016'. This report is based on the study of 166 selected conventional Indian MFIs operating.

In the following paragraphs, the performance of Al-Khair has been compared with the aggregate performance of the conventional MFIs (industry) on a few selected parameters used in the Sa-Dhan report. The parameters selected for the present research and their definitions as per Sa-Dhan are given below (SaDhan, 2016, p. xiv): 
- Average Borrower per Credit Officer (ABCO): $\mathrm{ABCO}$ is a measure of client-staff ratio. It is also known as Case Load.

- Average Loan Size (ALS): ALS represents the client per capita loan amount. It is calculated as: the loan portfolio divided by the number of clients of an MFI.

- Financing/Borrowing Cost Ratio (FCR): The total charge for taking on a debt obligation that can involve interest payments and other financing fees.

- Capital Adequacy Ratio (CAR): CAR is the means of measuring the solvency level of MFIs which is an important indicator of risk-bearing ability of the entities. It is the propor-tion of the capital/own funds held by an MFI against its total assets.

- Operating Expense Ratio (OER): Ratio of staff, travel, administration costs, other over-heads and depreciation charges of the MFIs (nonfinancial costs) to the average loan por-tfolio during a year.

- Operating Self Sufficiency (OSS): OSS shows the sufficiency of income (operating income and investment income) earned by MFIs to cover the costs like operating cost, loan loss provisions, and finance costs incurred for conducting operations.

- Return on Asset (RoA): RoA is the universally accepted profitability measure which, in essence, is the percentage net income earned out of total average asset deployed by MFIs during a given period, say a year.

- Return on Equity (RoE): RoE is the net income earned out of average equity of MFIs held by MFIs during the given period.

- Yield on Portfolio (YoP): YoP represents total income from microcredit operation-interest income, processing fee/service charge - earned out of average loan portfolio outstanding. It does not, include investment income. It is a good proxy/surrogate for loan interest rate.

The parameters selected from the Sa-Dhan report for the present study can be divided into three sets for evaluating the performance of Al-Khair with respect to the Indian MFI industry: a) Those parameters on which a direct comparison is possible of Al-Khair with conventional MFIs.

b) Those parameters on which a direct comparison is not possible of Al-Khair with conventional MFIs due to fundamental operational differences.

c) Those parameters on which a direct comparison is not possible of Al-Khair with conventional MFIs due to differences in mandate.

The parameters on which direct comparison is possible are: ALS and CAR. As per the Sa-Dhan report 2016, for conventional Indian MFIs the ALS is INR 11,425 and CAR is $19.39 \%$ (Sa-Dhan, 2016, p. xviii). As per the current study, in case of Al-Khair, the ALS is INR 8,477 and the CAR is $15.8 \%$.

Since ALS for Al-Khair is $26 \%$ lower than the conventional MFIs, it indicates that Al-Khair is either reaching out to poorer sections of the population compared to conventional MFIs or the higher ALS in case of conventional MFIs points to the overselling indulged in by the MFIs.

CAR is higher in case of conventional MFIs. It is partly a reflection of the better equity funding they are able to attract as compared to Al-Khair. This is broadly in line with the trend globally in this respect when mutuals or cooperatives are compared with privately funded financial institutions.

The parameters on which a direct comparison is not possible due to fundamental operational differences are: ABCO, FCR, and OER. As per the Sa-Dhan report 2016, for conventional Indian MFIs the ABCO is 440 borrowers, FCR is $13.3 \%$ and OER is $10.2 \%$ (Sa-Dhan, 2016, p. xviii). As per the current study, in case of Al-Khair, the ABCO is 149, FCR is $0 \%$ and OER is $20.2 \%$.

It is worth mentioning here that there are fundamental operational differences between $\mathrm{Al}$ Khair and the MFIs. Whereas the MFIs receive the bulk of their loanable funds as advances from banks and therefore do not need to either deploy manpower or incur costs for this purpose, Al-Khair has to raise its funds through its own operations. Moreover, since these funds do not attract any interest, they are in the nature of demand deposits. As a consequence, they exhibit a high velocity of movement leading to 
incurrence of substantial costs - relatively higher than the cost of deploying the funds. As a result, whereas Al-Khair has zero FCR (as against $13.3 \%$ for MFIs), its OER is much higher $(20.2 \%)$ than that of the MFIs (10.2\%).

As far as ABCO is concerned, due to the additionnal deployment of manpower on mobilization in case of Al-Khair, its ABCO is naturally lower (152) than that of the MFIs (440). Further, as many of the employees of Al-Khair are engaged in mobilization as well as deployment of funds, it is difficult to segregate those employees who are dealing only with loans.

The parameters on which a direct comparison is not possible due to differences in mandate are: OSS, RoA, RoE, and YoP. As per the Sa-Dhan report 2016, for conventional Indian MFIs the OSS is $113 \%$, RoA is $2.2 \%$, RoE is $11.6 \%$ and $\mathrm{YoP}$ is $21 \%$ (Sa-Dhan, 2016, p. xviii). As per the current study, in case of Al-Khair, the OSS is $101.6 \%$, RoA is $0.29 \%$, $\mathrm{RoE}$ is $1.9 \%$ and $\mathrm{YoP}$ is $20.5 \%$.

Whereas Indian MFIs are now unabashedly focused on earning profit, Al-Khair's objective is primarily to promote sustainable livelihood and alleviate poverty. Following from this basic difference in the mandates of the two, it is obvious that Al-Khair has to inevitably display a lower performance on parameters concerned with profitability i.e. OSS, RoA, RoE and YoP. Further, Al-Khair's non-profit motivation is clearly visible in a comparison of its $\mathrm{YoP}$ (20.5) with its OER (20.2). For more details please refer to Table 6 below.

One may also note that the NPAs (NonPerforming Assets) of Al-Khair are less than 1\% of outstanding loans ${ }^{(6)}$ and almost all its loans are secured loans.

From the discussion above, it can be said that despite a variation in the ratios in terms of absolute figures, the performance of Al-Khair in comparison to the conventional MFIs, in view of the operational and mandate differences highlighted above, has been better. However, the scope for further improvement and growth cannot be ruled out.

\section{Review of Al-Khair Operations from a Sharī'ah Perspective}

After having discussed the operations and the overall performance of Al-Khair, in this section the operations of Al-Khair are reviewed from a Sharī'ah perspective.

For any institution providing interest-free financial services, there are three important operational aspects on which the Sharīah compliance has to be ensured. These aspects are:

- Nature and mechanism of payment to depositors,

- Nature and mechanism of service charges being collected from the borrowers on demand loans, and

- Nature and mechanism of profit or profit and loss shared with borrowers on business loans.

In case of Al-Khair, as no returns are paid to depositors, hence, only the latter two aspects are required to be reviewed in the light of Shari 'ah to ensure that these aspects comply with the Sharī ah and are in line with the basic objective of the institution i.e. interestfree operations.

\subsection{Collection of Service Charges on Demand Loans}

In interest-free organizations advancing loans, service charges should be levied only to recover the cost incurred on providing financial services. Keeping this in view, the current policy of Al-Khair relating to service charges has been designed with the intention of merely recovering its cost of operations (service charges based loans). In this connection, Al-Khair head office has drafted a 'Service Charges Reference Sheet' containing a tabulation of the amounts of service charges to be collected on loans of different amounts. In practice, the service charges are levied and debited to the loan at the time of sanction of the loan and recovered as part of the installments (inclusive).

(6) As per the information provided by Al-Khair Managing Director over telecom dated 25-10-2017. 
Table (6) Comparative Performance Analysis of Al-Khair with Indian MFIs as on March 2016

\begin{tabular}{|l|c|c|c|}
\hline \multicolumn{1}{|c|}{ Parameters } & Unit & Indian Microfinance Industry & Al-Khair \\
\hline ALS & INR & 11,425 & 8,477 \\
\hline CAR & $\%$ & 19.39 & 15.8 \\
\hline ABCO & Nos & 440 & 152 \\
\hline FCR & $\%$ & 13.3 & 0 \\
\hline OER & $\%$ & 10.22 & 20.2 \\
\hline OSS & $\%$ & 113 & 101.6 \\
\hline RoA & $\%$ & 2.2 & 0.29 \\
\hline RoE & $\%$ & 11.6 & 1.9 \\
\hline YoP & $\%$ & 21 & 20.5 \\
\hline
\end{tabular}

(Data Source: Al-Khair Annual Report 2015-16 and Sa-Dhan Report 2016)

The rate of service charges underlying the preparation of the service charges chart is determined at the time of Al-Khair budget by calculating the ratio of budgeted expenditure to the budgeted average funds to be deployed in all financing and loan products during the forthcoming year. The budgeted expenditure for the forthcoming year is estimated on the basis of the expenditure of the previous year and budgeted activity levels for the forthcoming year in comparison to those of the previous year.

According to Accounting and Auditing Organization for Islamic Financial Institutions (AAOIFI), it is permissible for interest-free organizations to collect service charges so long as they are only meant to recover the actual cost incurred on providing such services. Any charges in excess of the actual cost are prohibited. The fundamental rule is that each loan bears its own specific charges (AAOIFI, 2015, p. 520).

If Al-Khair's method of calculation and collection of service charges (on service charges based loans) is reviewed in the light of AAOIFI stipulations, then it faces the following Sharī ah objections:

(i) Firstly, the amount/percentage of service charges to be levied is determined on the basis of assumption and not on the basis of the actual cost incurred.

(ii) Secondly, as there is no cost segregation based on the type of loans, there are chances that the costs incurred on certain types of loans (business loans) are being charged to the other types of loans (demand loans).

(iii) Thirdly, the service charges levied on a loan are based solely on the amount of the loan and are not linked to the period for which it is sanctioned. Due to this a borrower who borrows a smaller amount and/or for a shorter period and the one who borrows a larger amount and/or for a longer period pay almost the same service charge (compared to the loan amount). It has to be understood that not only the amount of loan but also the loan tenure will have an impact on the overall cost incurred.

(iv) Fourthly, the proportion of a loan repaid earlier has a positive impact on overall cost, whereas the proportion of a loan repaid with a delay has a negative impact. This impact has to be reflected in the calculation and collection of service charges. But such a provision is not inbuilt in the current method of Al-Khair. Due to this reason, there is a strong likelihood of one person benefiting at the cost of another, which is 'unjust' and is prohibited as per Sharī'ah.

In view of the above observations, the current method of determination, application, and collection of service charges of Al-Khair needs to be modified in line with the Shari 'ah stipulations.

\subsection{Collection of Profit Share on Business Loans}

In Islamic finance, mushārakah and mudārabah are the two main modes in which profit and loss can be shared. According to AAOIFI, in both of these types of modes, the profit to be shared should be in a ratio of the actual total profit realized and not as a predefined rate or a lump-sum amount linked to capital or on expected profit basis. The losses in case of mushärakah, should be shared between the partners only according to the capital contribution 
ratio whereas, in the case of mudarabah, the losses should be borne only by the party who is contributing the capital (AAOIFI, 2015, pp. 333-334 \& 374).

If Al-Khair's method of calculation and distribution of profit and loss (on business loans) is reviewed in the light of AAOIFI stipulations, then it attracts the following Sharī'ah objections:

(i) First, in case of Al-Khair's business loans, as the amount of profit is debited to the borrower's account at the inception of the loan itself, it seems the borrowers are entitled to pay the profit share of Al-Khair on the agreed terms irrespective of the actual profit realized from the business by the borrower. Moreover, it appears that the Society is not sharing the loss, if any, accrued on account of the business/investment, which is a necessary condition for the financing to be Sharī'ah compliant.

(ii) Second, even assuming that for ease, initially the profit sharing is tentatively determined on the basis of self-declaration by the borrower, it is incumbent that subsequently a track should be kept on whether the actual results conform to the initial assumption or not. In the absence of such tracking, there could even be a possibility of the borrower ending up paying the predetermined profit in spite of making losses.

In view of the above observations, there is a need to review the current profit determination, calculation and collection method adopted by Al-Khair for its business loans.

The above-mentioned are some of the potential challenges facing Al-Khair regarding its operations from the Sharīah perspective. The authors of this paper have consciously used the word 'potential' because these challenges are more specifically related to the method of calculation and collection of service charges and profit and loss sharing.

Notwithstanding the discussion above, the percentage of cost incurred on the operations of the Society and the average percentage of income collected on the average loans outstanding during the latest period (2015-16) is almost equal. This means that neither the Society itself nor any of the persons whose funds are involved, is directly benefiting from the income generated. Hence, objectively it is complying with its vision to be Sharīa ah compliant.
It is to be clarified here that the views presented in the above paragraphs are based on the authors' limited understanding of Al-Khair's concept of service charges, profit sharing, and AAOIFI Sharīah stipulations. The objective of bringing these issues here is to provide a base for further study and research in order to draw final conclusions.

\section{Recommendations}

On the basis of an in-depth study conducted on the operations of Al-Khair from different perspectives, the following recommendations are made:

\subsection{Sharī'ah Review of Operations}

It was found during the study that Al-Khair has its own method of determining service charges and profit share. As discussed in the above paragraphs, the current methods of determining the service charges and share of profits must be reviewed so as to ensure that the lacunae and obvious shortcomings in the respective methods are addressed suitably and thereby, not only Al-Khair's social concerns but its core Sharī ah objectives too, are achieved in practice.

One way to achieve this objective could be to implement the Scientific Costing and Re-Days System as suggested by Khatkhatay and Nisar (2014, pp. 33-48). This system helps the institution in identifying, recording and treating various costs on the basis of the activities in which they are incurred. This system will also facilitate in the collection of service charges in such a way that it avoids any kind of injustice on the part of both customers and the institution. In addition, in case of profit sharing finance, a system to determine actual profit generated from the investments needs to be adopted so that the profit sharing between the parties should not be merely on the basis of assumption but on the basis of actual outcome of the business.

\subsection{Regular Performance Review}

As has been presented in the above paragraphs, the overall performance of Al-Khair on various performance measures seems to be good. The performance of Al-Khair in comparison to conventional MFIs, in view of the operational and mandate differences highlighted, has also been better. However, Al-Khair needs to have a process of regular performance review, especially to broaden the outreach and minimize costs. This would help the institution in becoming more viable and efficient in the long run. 


\subsection{Regular Program of Training and Development}

In the context of the Indian environment where Islamic finance products are still at a nascent stage and there is a dearth of manpower trained in offering Islamic finance products, it is essential that Al-Khair institute has an on-going program of training for its staff, not only in Islamic finance but also in the basics of finance, co-operation and taxation for personnel whose work is impacted by these subjects. The Society could initially tie up with one or more external agencies for this purpose. The intention should, however, be over time, to also develop in-house expertise in this area so that reliance on external sources can be minimized. Apart from improving the capabil-ities and efficiency of the staff, such a program will also enrich their work and provide greater satisfaction.

\subsection{Separate Inspection and Internal Audit Cell}

This suggestion is linked to the previous one. For an institution with far-flung branches, dealing with small -scale financial products, it is extremely important to have a strong inspection and internal audit department which reports directly to the Board. The department should be adequately staffed, with well-trained personnel who are continuously involved in branch inspections round the year. With the trend in regard to statutory audits, such internal controls are an important tool to ensure that the interest of the Society is protected.

In the context of the observations during our study, inspections will be a powerful tool to ensure compliance with policy guidelines, both Shari' ah and others, and provide Head Office management with information as to the operational areas and branches it needs to concentrate on.

\subsection{Organize Awareness Programs for Customers/ Borrowers}

As discussed above, during our interaction with customers/borrowers of Al-Khair at Patna Central and Phulwari Sharif branches, it was found that the customers/borrowers are not aware of the unique features of Al-Khair's operations. Hence, it is suggested that Al-Khair should organize frequent interactive sessions with members/customers/borrowers to create awareness about interest-free financial con- cepts and practices. The more customers are aware of the actual nature of practices of the Society, the more closely and actively they will be involved with the functioning of the Society and enable it to achieve its objectives.

\section{Conclusions}

Microfinance has emerged as a key channel for financial inclusion. Given the low penetration and huge potential demand for microfinance services, there is a great scope for utilizing the IFMIs as co-existing channels to serve the unbanked population.

IFMFIs do not charge 'interest' and principally operate by balancing financial goals and social objectives. Moreover, utilizing innovative products, these institutions share risk and benefits with the customers. In view of these holistic features, there is a hope that these institutions can become a boon for the poorest of the poor.

Hence, whether from the microfinance low penetration (demand) perspective or due to the interestfree nature, policy makers and researchers need to take immediate note of interest-free microfinance.

As far as Al-Khair is concerned, it is clear that AlKhair has exhibited an in-principle commitment to be an interest-free institution. Already Al-Khair has established itself as a well-known cooperative credit society operating on an interest-free basis. It has also adopted modern technology, implemented computerized procedures and brought quality human resources into the organization. These factors make it a transparent and efficient organization. Its growth from a small society to a big organization having 13 branches in different parts of India is a proof that AlKhair is operating efficiently.

In respect to transparency, involvement of primary members in the activities and philosophy of the organization and accent on adoption of correct accounting principles, Al-Khair is a model for other IFMFIs to emulate.

A few potential issues have been highlighted and listed in the current paper which need further research and discussion. We hope that the recommendations made in the paper will help Al-Khair in further improvement and growth if adopted and implemented. 


\section{References}

Accounting and Auditing Organization for Islamic Financial Institutions (AAOIFI). (2015). Shariah Standards. Manama, Bahrain.

Ameer, P. A. (2013). Finance for the Poor: An Exploratory Study of Interest-free Microfinance Initiative at Kuthiyathode Panchayath, Alappuzha, Kerala, India. International Journal of Economics, Commerce and Research, 3(2), 103-116.

Andhra Pradesh Micro Finance Institutions (regulation of money lending) Ordinance (APMF Ordinance). (2010). Hyderabad, India: Government of Andhra Pradesh. Retrieved from: http://indiamicrofinance.com/wpcontent/uploads/2010/10/Andhra-MFIOrdinance.pdf

Al-Khair Cooperative Credit Society Limited. (2012). Al-Khair Annual Report for the period 201112. Patna, India: Author.

Al-Khair Cooperative Credit Society Limited. (2013). Al-Khair Annual Report for the period 201213. Patna, India: Author.

Al-Khair Cooperative Credit Society Limited. (2015). Al-Khair Annual Report for the period 201415. Patna, India: Author.

Al-Khair Cooperative Credit Society Limited. (2016). Al-Khair Annual Report for the period 201516. Patna, India: Author.

Ashraf, Ali, Hassan, M. Kabir, \& Hippler III, William J. (2014). Performance of Microfinance Institutions in Muslim countries. Humanomics, $30(2), 162-182$.

Ajmal, Arshad. (2010). Interest-free Microfinance in India: Exploring the Cooperative Model Option. Paper presented at the International Seminar on Islamic Finance in India: Products, Institutions and Regulations, 4-6 October, 2010, Kochi, Kerala, India.

Bagsiraj, M.G.I. (2003). Islamic Financial Institutions of India: Progress Problems and Prospects. Jeddah: Scientific Publishing Centre, King Abdul Aziz University.

Karim, N., Tarazi, M., \& Reille X. (2008). Islamic Microfinance: An Emerging Market Niche (Focus Note No. 49). Washington DC: CGAP, August. Retrieved from: http://siteresources.worldbank.org/ EXTDEVDIALOGUE/Resources/5372971241045572558/Islamic_MicroFinance.pdf
Khan, Javed Ahmed, \& Nisar, Shariq. (2004). Collateral (Al-Rahn) as Practiced by Muslim Funds of North India. Journal of King Abdulaziz University: Islamic Economics, 17(1), 17-34.

Khatkhatay, M. H., \& Nisar, Shariq. (2014). Conceptual Understanding of Service Charges on Loans and its Application in Islamic Microfinance. Sahulat - a Journal of Interest Free Microfinance, 2(1), 33-48.

Ledgerwood, J. (1999). Microfinance Handbook: An Institutional and Financial Perspective. Sustainable Banking with the Poor Project. Washington, D.C.: World Bank.

Malegam, Y. H. (Malegam Committee Report). (2011). Report of the Sub-Committee of the Central Board of Directors of Reserve Bank of India to Study Issues and Concerns in MFI Sector. Mumbai, India: Reserve Bank of India. Retrieved from: https://www.rbi.org.in/SCRIPTS/PublicationReport Details.aspx? UrlPage $=\& I D=608$

Mohammed, Wasiullah Shaik, Abdur Raqeeb, H., \& Waheed, Khalid. (2016). Islamic Finance in India: Financial Regulations Challenges and Possible Solutions. In Amit K Kashyap, \& Anjani Singh Tomar (Eds.), Financial Market Regulations and Legal Challenges in South Asia (pp. 263-285). Hershey, PA, USA: IGI Global.

Nisar, Shariq, \& Mizanur-Rahman, Syed. (2012). Minority Funds in India: Institutional Mobilizing of Micro Savings. In S. Nazim Ali (Ed.), Shari'acompliant Microfinance (pp. 181-205). Oxford, UK: Routledge.

Obaidullah, Mohammed, \& Khan, Tariqullah. (2008). Islamic Microfinance Development: Challenges and Initiatives (Dialogue Paper No. 2). Jeddah: Islamic Research and Training Institute, Islamic Development Bank.

Planning Commission, Government of India. (2009). A Hundred Small Steps: Report of the Committee on Financial Sector Reforms (Raghuram Rajan Committee Report). New Delhi: Sage Publication.

Sa-Dhan, The Association of Community Development Finance Institutions. (2016). The Bharat Microfinance Report 2016. New Delhi: Author. Retrieved from: https://www.microfinancegateway.org/sites/default/f iles/publication_files/the_bharat_microfinance_repo rt_2016-min.pdf 
Wasiullah Shaik Mohammed is a Research Scholar and pursuing a $\mathrm{PhD}$ in Management in the area of Interest-free Microfinance from the B.S. Abdur Rahman Crescent Institute of Science and Technology, Chennai, India. He has an MBA in finance from the prestigious Osmania University, Hyderabad. He has worked as a Financial Analyst and as a Financial Research Analyst, structuring Sharı̄'ah-compliant financial contracts and products in real estate, microfinance, manufacturing and retail business. He has presented several research papers at various national and international universities and seminars. He has been associated with the development and production of course materials for teaching Islamic finance and has also lectured on the subject at various universities. His "Islamic Finance in India: Financial Regulations, Challenges and Possible Solutions" is among the few papers included in the recent specialist publication on financial markets regulation as part of Advances in Finance, Accounting and Economics (AFAE) Book Series in the US.

Email:wasism@gmail.com

Khalid Waheed is a $\mathrm{PhD}$ in Economics with specialization in Islamic Banking and Finance. He earned his $\mathrm{PhD}$, M.A., and. B.A. (Hons.) in Economics from a premier central university of India viz. Aligarh Muslim University (AMU). Prior to his education at AMU, he also completed eight-year traditional Sharī'ah and Arabic education from a reputed religious seminary of North India, Jamiatul Falah, Azamgarh, UP. He then further completed a course of Advance Studies in Islamic Jurisprudence from al-Ma'had al-'Ali al-Islami, Hyderabad, India. He has been associated with teaching for the last nine years. Presently he is working at the Department of Management Studies, B.S. Abdur Rahman Crescent Institute of Science and Technology, Chennai, India as an Assistant Professor of Economics and Islamic Finance. He has worked on various projects sponsored by private and government institutions such as Ministry of Small Scale Industries, Government of India and Centre for InterDisciplinary Studies (ICDS), Aligarh, etc. He has also been associated with the Indian Centre for Islamic Finance (ICIF), New Delhi and served as a member of the Indian Association for Islamic Economics (IAFIE), Aligarh during 2002-2008. He is a life time member of the Indian Economic Association (IEA), a registered body of Indian Economic Professionals established in 1917.

Email:kwfalahi@bsauniv.ac.in; kwfalahi@gmail.com 


\section{التمويل الأصغر بدون فوائد في الهند: دراسة حالة لجمعية الخير التعاونية للائتمان}

$$
\begin{aligned}
& \text { وصي الله شيخ محمد " و خالد وحيد** } \\
& \text { باحث، "أستاذ مساعلد } \\
& \text { جامعة ب. س. عبد الرحمن معهل العلوم والتكنولوجيا ، الهند }
\end{aligned}
$$

المستخلص. تقدم مؤسسات التمويل الأصغر الإسلامي خدمات فعالة في جميع أ نحاء العالم و منها

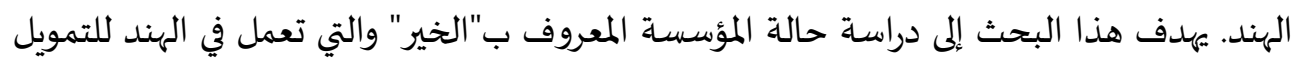

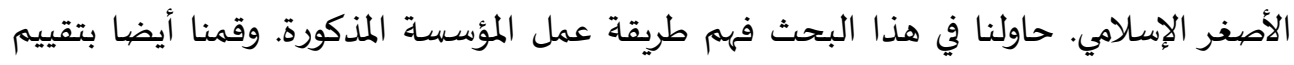

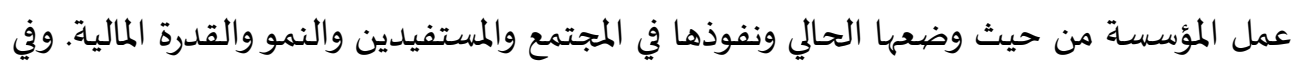

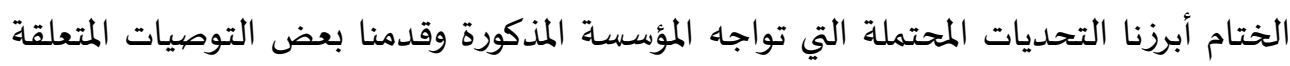
بالنمو والتنمية للأحسن. 